\title{
Growing but as a sideline An overview of modern Shan monastic education
}

\author{
Venerable Khammai Dhammasami, DPhil \\ International Theravada Buddhist Missionary University, Yangon \& \\ Executive Secretary, International Association of Buddhist Universities
}

[A draft. Please do not quote.]

\section{Background}

I have argued elsewhere that the decline of in-depth study in monastic education in Burma and Thailand has been due mainly to the loss of control by the monastic educationists to the state who introduced state-controlled written examinations in the mid $17^{\text {th }}$ century. ${ }^{1}$ The formal examinations were introduced to stop conscripts from joining the monastic order during the times the two countries were at war. The introduction of the formal examinations means individual teaching monasteries handed over to the temporal authority the power to design their own syllabuses which a normal university enjoys today. While the state-controlled or state-sponsored, depending on how you see it, examinations held only in the capital for the first two centuries, they were later expanded to provinces, in Thailand under King Rama V (1868-1910) as a part of his centralization programme, and in Burma under the British colonial government as a part of their pacification policy to bring back normalcy. Since then, monastic education in those two countries has gradually come to be confined to narrow syllabuses of the state-controlled examinations. The main examinations were known in Burma as pathamapyan and in Thailand as parian. Both countries have since extended these exams, in Burma to a higher level call dhammacariya degree, and in Thailand to a lower level called nak tham.

In Burma, the pathamapyan were suspended in 1885 by the British after they had overthrown the last Burmese king, Thibaw. This was considered a blow to the Buddhasasana by senior Buddhist monks. The leading sayadaws in Mandalay were one in their opinion that "the $s$ Asana of the Lord Buddha should no longer be neglected as it is now, or the $s$ Asana will gradually decline and disappear; even if one cannot support the sAsana with material requisites as the Burmese kings did, good Buddhists should come together to carry out this duty as far as they could, and if the sayadaws were also to promote the sAsana through the teaching, the sAsana would certainly prosper". ${ }^{2}$ As a result, the sayadaws, former courtiers and business community and even some Shan Saofas (Sawbwas) who altogether initiated a formal examination board in 1898 in Mandalay. ${ }^{3}$ This board of examination is popularly known today as the sakyasiha examinations, but those days it was known in Burmese as amyotha samaybwei, "nationalist examinations", indicating the sentiment against the British. Almost at the same time, there was a similar nationalist board of Buddhist monastic examinations

\footnotetext{
${ }^{1}$ Dhammasami, Khammai, Ven., "Idealism and Pragmatism: A Dilemma in the current monastic education system of Burma and Thailand" in Buddhism, Power and Political Order, pp.10-25.

${ }^{2}$ The Pariyatti SAsanahita hnit taya pyi thahmaing, p.24.

${ }^{3}$ Ibid, p.13.
} 
known as Cetiyangana because it was based in the famous Shwedagon Pagoda compound where crucial political initiatives by the nationalists were made. From the 1940s, these two boards of examinations were to become a precursor of other Buddhist monastic examinations in different regions of the country. Indeed, today almost all cities and towns of considerable size will have a board of monastic examination of its own. But today instead of nationalist exams, they are simply known as athin samaybwei, "nongovernmental examinations".

It is within this dual context, on the one hand, of the existence of the state-controlled monastic education started in the $17^{\text {th }}$ century, and, on the other, the existence of nationalist examinations which began as a reaction to the British rules and which have since mushroomed in many parts of the country, that I will present an overview of modern monastic education in the Shan State.

\section{Boards of monastic examinations in the Shan State}

In 1956, just after the chatthasangayana, the Sixth Buddhist Council, (1954-56) individual efforts by two learned Shan monks led to the founding of Sangha examination boards to promote the study of the Tipitaka in Shan. Both of them were educated in the Burmese tradition and hold a dhammacariya degree conferred by the Government of the Union of Burma.

One of the two boards of examinations was at the Dhammodaya Monastery in Kengtung in eastern Shan State and the other in Mong Nang, a village near a town called Kesi in central Shan State. The two founders of the two examinations shared some common characteristics: they wanted to bring Shan monastic education in line with the Burmese which emphasized the study of Pali canonical and commentarial literature. Both were some of the earliest monks in the country to have obtained the dhammacariya degree from the government-sponsored Dhammacariya Examinations. Besides, both compiled textbooks for their pupils, using materials from the Pali and Burmese sources.

One important difference between them, however, was that the founder of the Dhammodaya Examinations in Kengtung, Venerable Aggamahapandita Ajeyyya, compiled all his textbooks in the vernacular, much similar to the nak tham examinations textbooks compiled in Thailand in the early $20^{\text {th }}$ century by Prince Patriarch Wachirayanwarorot (1860-1921), who was half-brother of King Chulalongkorn. Here it seems both the Prince Patriarch and Venerable Ajeyya believe that popularizing the Buddhist teaching can only be effectively carried out in a vernacular language. So, in the Dhammodaya Examinations curriculum there was no teaching of Pali. On the contrary, his counterpart in Mong Nang, Venerable Aggamahapandita Rajinda, used a mixture of paraphrase and pure Shan translation; and he taught Pali to his students.

In brief, the creation of the examinations by these two Shan scholar-monks was to promote canonical-based Buddhism in the Shan language. 
I have the good fortune of knowing both of them personally; but I think they did not know each other personally when they were setting up examination boards in their hometown. This is not to say they might not have heard of each other. For both became prominent when the Shan became very conscious of the danger posed to their cultural identity within the Union of Burma. Any movement by the non-Burman minority nationalities, including those in education and culture, at this time could be considered part of that identity-consciousness.

This anxiety about the national identity of the Shan was shared by other non-Burman ethnic groups in Burma, because they were aware of the problem of assimilation, fearing for the future of their cultural identity. By the time the Shan Sangha was setting up local boards of exam in the 1950s, their Mon counterparts have already successfully adapted to the Burmese cultural dominance by embracing the government sponsored-Pathamapyan and Dhammacariya exams but in the Mon language. Indeed, the Mon Sangha in Thailand, the khana rAman, did a similar thing when they negotiated with the Siamese State; I am not sure exactly when but they were allowed to conduct the parian exams in the Mon language. Indeed, the Mon Sangha in Thailand managed to get a better deal when they were allowed to have a separate syllabus that concentrated entirely on the Vinaya-pitaka, rather than the whole three pitaka as in the Thai language parian. As we all know, a Mon Mahathera, Maha Yen Buddhavamso ${ }^{4}$, who was the product of the Mon Parian examinations, helped settle the doubts of King Mongkut concerning the Vinaya rules and practices while he was a bhikkhu.

So far, in both Burma and Thailand the Mon are the only minority group to have secured the rights to formally teach the dhamma in their own language.

In Burma, the awareness of the national identity among the non-Burman nationalities became stronger in the mid 1950s; we see among the educated Shan people and Sangha an aspiration similar to that of the two founders of the Shan Buddhist exams in Kengtung and Mong Nang. In 1957, a board of Buddhist monastic examinations for the whole Shan State was created in Pang Long. As we all know, Pang Long is famous for a political agreement, Pang Long Treaty, that was signed nine years earlier, in 1947, between the Shan, the Burman or Bamar which is the majority group, Kachin, Kayah and Chin, effectively forming the present Union of Burma."

The examinations in Pang Long, known as Pariyatti-saddhammapala, were to be conducted in the Shan medium only. In a in few month's time, the Pang Long Examinations Board will celebrate its golden jubilee. I myself hold a dhammacariya degree in the Shan medium from this exam board. The syllabuses are exactly as in the government-sponsored dhammacariya examinations: the study of Dhammasangani, its

\footnotetext{
${ }^{4}$ He was conferred a royal title Phra Sumed and lived at Wat Bovonives. See also Pavaresvariyalongkorn,

"A Brief Account of King Mongkut (Rama IV): from the time of his ordination as a bhikkhu until his passing-away" Visakhapuja, 2513 (1970), pp.20-21. See also Ploichum, Khana song raman (The Mon Sangha), pp.152-154. Maha Yen Buddhavamso was the founder of the only Ramannya-nikaya in Burma; the nikaya is known after him as Maha Yen Gaing; the name in full is Maha Yen dhammayuttika-nikaya.

${ }^{5}$ Successive governments of the Union of Burma mark the day, $12^{\text {th }}$ February, as the Union Day.
} 
commentary Atthasalini; the Silakkhandhavagga-Pali and its commentary the Sumangalavilasini; the Parajikakanda-Pali and its commentary the Samantapasadika. The exams are arranged over six days; three days to test your translation skills and three days your interpretation skills. The interpretation skills include the use of texts, for example, the tika (sub-commentaries) to the attakathas, the Nettipakarana, the Patthana in the Abhidhamma-pitaka, the Subodhalankara, the Vuttodaya, the Kaccayana Pali grammar, the Abhidhammatthasangha.

The difficult with students for the Shan examinations is that there is no monastery teaching those texts in Shan. They have to learn them in Burmese and then sit the exam in Shan. However, the Shan translation of the canonical work is available but not commentaries. Because of this difficulty, we have some Shan bhikkhus who hold a dhammacariya degree in Burmese but not in Shan.

Not very far from Pang Long, just twenty six miles away, and in the same year, 1957, a small town, Laikha, also set up its own Buddhist examinations for the monks. This exams board was to promote the study of the Tipitaka in Shan but only for those living locally.

Within the last fifty years, the number of the Shan Buddhist exam boards has gone up to over twenty and seems to increase even further. Today nearly half of towns and cities in the Shan State have local examinations, in the tradition of nationalist exams under the British, to promote the study of Tipitaka-based Buddhism in Shan. For the last five decades, roughly there is a new exam board in the Shan medium being set up every two and half years. And, none has gone defunct.

\section{Conclusion}

Here it is obvious that the creation of these formal boards of examination shows the influence on contemporary Shan Buddhist monastic learning system of Burmese Buddhist education. Before this, the long-established Shan monastic learning mainly focuses on the type of literature that Jotika Khuryen and Ven. Pannyavamsa present here in this conference. Many of them were compiled in poetic style (lanka/ lik-laung) and took into account the needs of not just scholars and students but also of the ordinary lay Buddhists. That is to say Buddhist ethics are explained using some sutta, some Jataka stories and local folktales. They can be the subject of serious study by learned scholars, and at the same time entice illiterate audience on the uposatha days when devotees observe a two-day retreat (kam-sil non-kyaung) in the monastery or when there is a religious gathering in the village.

The influence of the Burmese Buddhist scholastic system over the Shan monastic learning in recent decades becomes clear if we compare the syllabuses of the statesponsored exams in Burmese and the main Shan Buddhist examinations from Pang Long. (A Table with PopwerPoint) 
None of these syllabuses have lik-laung in the curriculum. ${ }^{6}$ As a result, none of the important teaching monasteries in the Shan State teaches lik-laung. Hardly, any scholar of my generation knows how to compose one.

Over the years, the Shan Sangha educationalists have had to face a difficult choice. If they do not follow closely the curriculum of the state-sponsored Pathamapyan and Dhammacariya exams, there may never be hope of the government recognizing their qualification. So with a view to obtain formal recognition by the government and the Burmese Sangha educationists, it was decided that the curriculum of the Shan Buddhist exam boards should follow as closely as possible the curriculum of the pathamapyan and dhammacariya examinations. In the meantime, this will help also the Shan Sangha students who will have to inevitably sit for the government-sponsored exams to receive recognition for their scholarship.

While this choice seems to have potential to solve the problem of recognition in the long run, it at the same time raises another problem: the preservation of the early Shan monastic learning system, which was at the heart of the Shan literary identity.

At this point in time, the potential of receiving recognition from the government for the qualifications from the Shan Buddhist exams boards has not materialized; nor has the government given any hint of expanding the pathamapyan into the Shan medium like in the Mon. Among these uncertainties, what we can be certain of is that the growth of the Shan Buddhist monastic examinations boards over the years seem to be taking place not only as a sideline but also at the expense of the traditional Shan Buddhist literature such as Lik-laung, the unique characteristics of the Shan literary identity for which those exam boards were founded.

\section{Selected Bibliography}

In Burmese

1. Cetiyangana pariyatti dhammanuggaha athin sarpyanbwe simyin-upade (The Rules and Regulations of the Examinations of the CetiyaNgaBa DhammAnuggaha Association), Rangoon, (undated).

2. Htut, Than, U Myanmar naing gnan phongyi kyaung pyinnyayay thamaing (History of Monastic Education in Burma) (MA Thesis at Rangoon University), Ohn Pin Press, Rangoon, 1980.

3. Kyan, Ma "Thibaw min patomu khyain ka british myanmar naing ngan e pyinnyayay achay anay (The State of Education in British Burma at the Fall of Thibaw)" Journal of Burma Research Society, XLIX, II, Rangoon, Dec. 1966.

4. Maha Yen Sayadawpayagyi e atthokpati akyin (A Brief Biography of Maha Yen Sayadaw)" Mahayin gaing lon saingyar yayphay sarmaypwe hnint dhammavinaya sarpyan pwe tawgyi hnit

\footnotetext{
${ }^{6}$ In fact, this loss of traditional learning is not unique to the Shan. Even the Burmese have lost that creative part of their learning system. Highly regarded works of Ledi Sayadaw, for example, forms no part of the pathamapyana nd dhammacariya exam syllabus. The lack of creativity in languages as well as in depthstudy of the Tipitaka was pointed out by the leading sayadaws in 1980. For more see Naing gnan daw thangha mahanayaka aphwe pariyatti simankein (Report of The State Sangha MahAnAyaka Committee's Pariyatti Education Scheme).
} 
yarpyi matgazeen (Centenary Magazine of the Mahayin-nikaya and Dhammavinaya Examinations), [a trilingual magazine], Rangoon, 1999.

5. Naing gnan daw thangha mahanayaka aphwe pariyatti simankein (Report of The State Sangha MahanAyaka Committee's Pariyatti Education Scheme) (3rd Draft), Ministry of Religious Affairs, Rangoon, 1981.

6. Pariyatti thathanahita athin hnit taya pyi thamaing, (History of the Centenary Pariyatti Sssanahita Association) Thukhawadi Press, Mandalay, 1998.

7. Pathamapyan sarmaybwe byahtankhyet hnint poksarhtok simyin (The Syllabuses and Rules and Regulations for Questions of the Pathamapyan Examinations), Dept. of Religious Affairs, Rangoon, 1998.

8. Phongyi kyaung pyinnya thinkyaryay mawgun (Records of Monastic Education), Ministry of Welfare, Rangoon, 1958.

9. Pondawgyi kyaung pyinnyayay sonsanyay asiyinkhansar hnint ovadacariya sayadaw mya $e$ akyanpaykyet mya (Report of the Enquiry Committee on the National Education in the Buddhist Monasteries and the Advice of the Advisor-Sayadaws), Superintendent, Govt. Printing and Stationery, Rangoon, 1948.

10. Royal Orders of Burma, 10 vols., ed. \& introduction in English by Than Tun, Centre for Southeast Asian Studies, Kyoto University, Kyoto, 1983-1991.

11. The Pali University and Dhammacariya Act, 1950, Ministry of Information, Rangoon, 1951.

\section{In English}

12. Dhammasami, Khammai, Ven., Between Idealism and Pragmatism: A Study of Monastic Education in Burma and Thailand from the Seventeenth Century to the Present (Unpublished doctoral thesis), University of Oxford, 2004.

13. Dhammasami, Khammai, Ven., "Idealism and Pragmatism: A Dilemma in the current monastic education system of Burma and Thailand" in Buddhism, Power and Political Order, Ian Harris (ed.), Routledge, London, 2007.

14. Ishii, Yoneo "Ecclesiastical Examination in Thailand" Visakhapuja, Annual publication of the Buddhist Association of Thailand, Bangkok, 2515/1972.

15. Mangrai, Saimong, Sao The Padaeng Chronicle and the Jentung State Chronicle Translated, Centre for South and Southeast Asian Studies, University of Michigan, (Reprint), Anne Arbor, 2002.

16. Mendelson, E. Michael State and Sangha in Burma, Cornell University Press, Ithaca, 1975.

17. Myint, Myo The Politics of Survival in Burma: Diplomacy and Statecraft in the Reign of King Mindon, 1853-1878, (Unpublished PhD Dissertation) Cornell University, Ithaca, 1986.

18. Na Pombejra, Dhiravat A Political History of Siam under the Prasatthong Dynasty, 1629-1688, (Unpublished PhD Thesis), SOAS, University of London, 1984.

19. Reynolds, J. Craig The Buddhist Monkhood in Nineteenth Century Thailand, (Unpublished PhD Dissertation), Cornell University, Ithaca, 1972.

20. Report of the Pali University Inquiry Committee, Superintendent, Government Printing and Stationery, Rangoon, 1941.

21. Sein Ko, Taw "Pali Examinations" Burmese Sketches, Vol. I, British Burma Press, Rangoon, 1913.

22. Tun, Than "Ayut'ia Men in the Service of Burmese Kings, $16^{\text {th }} \& 17^{\text {th }}$ Centuries" Tonan Ajia Kenkyu (Southeast Asian Studies) Journal, vol. 21, No. 4, Kyoto University, Kyoto, 1984.

23. VajiraGABavarorasa, Prince The Life of Prince-Patriarch VajiraGABa, ed. \& trans. Craig Reynolds, Ohio University Press, Ohio, 1979.

24. Wyatt, K. David The Politics of Reform in Thailand: Education under King Chulalongkorn, Yale University Press, New Haven, 1969.

\section{In Shan}

25. Pariyatti-saddhamapala kien-sao tserng tai, khao tarng sao ha pi (The Silver Jubilee of the Pariyatti-saddhammapala Examinations), Pang Long, Shan State.

26. Tai noom, The Rangoon University Tai Youth Magazine, 1957-58, Rangoon. 
27. Wo nam tham pariyat (The Wells of the Dhamma), ( a commemorative book to mark $75^{\text {th }}$ Birthday of the Venerable Aggamahapandita Ajeyya), Kengtung, 2002.

In Thai

28. Parian ratchkarn thi ha (The Parian Degree Holders during the Reign of Rama V), Sophonphiphattanakorn Press, Bangkok, 2463 (1919).

29. Ploichum, Suchao Khana song raman nai prathet Thai, (The Mon Sangha in Thailand), Mahamakuta Royal University Press, Bangkok, 2544 (2001).

30. Prawat karn suksa khong khanasong (History of the Sangha's Education), Department of Religious Affairs, Ministry of Education, Bangkok, 2527 (1983). 